\title{
Application of IOS/Android Rapid Evaluation of Post-Earthquake Damages in Masonry Buildings
}

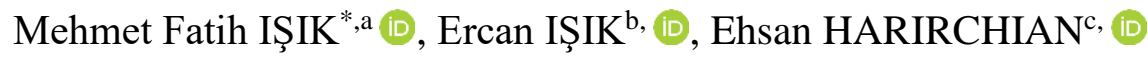 \\ ${ }^{a, *}$ Hitit University Department of Electrical and Electronics Engineering, 19030, Çorum, Turkey. \\ ${ }^{b}$ Bitlis Eren University Department of Civil Engineering, 13100, Bitlis, Turkey. \\ ${ }^{C}$ Institute of Structural Mechanics (ISM), Bauhaus-Universität Weimar, 99423 Weimar, Germany.
}

\begin{tabular}{l} 
ARTICLE \\
INFO \\
\hline \\
Received: 28.01 .2021 \\
Accepted: 21.04 .2021 \\
\hline \\
Keywords: \\
Web-Based Software \\
Masonary \\
Earthquake Damage \\
Rapid Eveluation
\end{tabular}

\begin{abstract}
One of the most important factors for the life to return to normal after devastating earthquakes is conducting reliable damage assessments, which have quantitative rules that do not vary from person to person. As a result of scientificaly based damage assessment, the housing problem can be mitigated, the economic burden of allowances spent for the destruction of the buildings with redundant destruction order will be eliminated, and the loss of life to occur in aftershocks can be prevented. In this instance, it was increased of siginificance of the first post-earthquake damage assessments. Rapid and scientific based of damage assessments is an important part of the modern post-earthquake disaster management. Masonry structures are at the top of the structures where earthquake damages occurred. The possibility of damage to these structures which have no engineering services is more likely. Damage assessment forms are used in the first damage assessment procedures. Damages can be assessed more rapidly and scientifically with the help of these forms. In this study, the ready-to-use form used for the earthquake damage assessment procedure for the masonry buildings was transferred to the web base, and the data to be obtained at the site were transferred to the database via tablets and smart phones. Keeping the earthquake damages in a memory system will contribute to the studies on earthquakes and the future earthquake regulations. As the data transferred to the web base will be accessible for different people, it will provide savings in terms of both time and staff. A php-based web interface was developed for the study due to its flexibility, speed and secure structure, and MySQL was preferred as the database. In this study, sampling was conducted for four masonry buildings with different damage levels caused by the October 23, 2011 earthquake in Van. Damage assessment procedures will be completed as soon as possible such as an application based on this study.
\end{abstract}

\section{Yığma Binalarda Deprem Sonrası Hasarların IOS/Android Hızlı Değerlendirilmesi Uygulamas1}

\begin{tabular}{l}
$\begin{array}{l}\text { MAKALE } \\
\text { BILGGISI }\end{array}$ \\
\hline Alınma: 28.01 .2021 \\
Kabul: 21.04 .2021 \\
\hline \\
Anahtar Kelimeler: \\
Web Tabanlı Yazılım \\
Deprem \\
Hizlı Değerlendirme
\end{tabular}

$\ddot{O} \mathbf{Z}$

Y1kıcı depremlerden sonra hayatın normale dönebilmesindeki en önemli unsurlardan biri de güvenilir ve kişiden kişiye büyük farklılıklar içermeyen nicel kuralları olan hasar tespitlerin yapılmasıdır. Bilimsel tabanlı yapılan hasar tespitlerin neticesinde barınma sorunu hafifletilebilecek, gereksiz yıkım kararı verilen binaların yıkımı için harcanan ödeneklerin ekonomik yükü ortadan kaldırılabilecek, artçı depremlerde meydana gelecek olan can kayıpların önüne geçilebilecektir. Bu aşamada deprem sonrası ilk hasar tespitlerinin önemi artmaktadır. Hasar tespitlerinin hılı ve bilimsel bir şekilde yapılması deprem sonrası modern afet yönetiminin önemli bir parçasıdır. Deprem hasarların oluştuğu yapıların başında yığma yapılar yer almaktadır. Herhangi bir mühendislik hizmeti almayan bu tür yapılarda hasar oluşma ihtimali daha yüksektir. İlk hasar tespit işlemlerinde hasar tespit formları kullanılmaktadır. Bu formlar yardımı ile hasarlar

*Corresponding author: mehmetfatih@ hitit.edu.tr

To cite this article: M. F. Işık, E. Iş̧1k ve E. Harirchian, "Application of IOS/Android Rapid Evaluation of Post-Earthquake Damages in Masonry Buildings", Gazi Journal of Engineering Sciences, vol.7, no.1, pp. 36-50, 2021. doi:10.30855/gmbd.2021.01.05 
daha hızlı ve bilimsel bir şekilde değerlendirilebilmektedir. Bu çalışmada yığma yapılar için deprem hasar tespit işlemi yapılırken kullanılan hazır form web tabanına taşınmış ve sahada elde edilecek veriler tablet ve akıllı telefonlar vasıtası ile veri tabanına aktarılması gerçekleştirilmiştir. Deprem hasarlarının bir hafıza sisteminde tutulması deprem ile ilgili yapılacak çalışmaları ve hazırlanacak deprem yönetmeliklerine katkı sağlayacaktır. Web tabanına aktarılan verilere farklı kişilerin erişim kolaylığı olduğundan hem zaman hem de personel açısından tasarruf sağlayacaktır. Çalışma için; esneklik, hız ve güvenli yapısından dolayı php tabanlı bir web arayüzü oluşturulmuş olup, veri tabanı için MySQL tercih edilmiştir. Bu çalışmada 23 Ekim Van depreminde farklı hasar seviyelerine sahip dört adet yığma bina için örneklendirme yapılmıştır. Bu çalışma ile hasar tespit işlemleri olabilecek en kısa sürede tamamlanabilecektir.

https://dx.doi.org/10.30855/gmbd.2021.01.05

\section{INTRODUCTION (GIRIŞ)}

Especially the devastating earthquakes in recent years and large-scale losses of life and property caused by these earthquakes brought up the studies, research on earthquake and the importance of the measures to be taken. In this context, post-earthquake damage assessments are one of the important steps of modern disaster management. Detection and management of all the information on the damaged structures after the earthquake is also important in terms of spatial planning and urban transformation [1$6]$.

The first post-earthquake damage assessments should be carried out as rapidly and practically as possible. Rapid damage assessments are unlikely in earthquakes with large-scale damages due to the size of the damage caused, and the lack of adequately specialized personnel. In such cases, non-specialized personnel are used, and this does not allow realistic damage assessments. Furthermore, the difficult field conditions and inadequate public resources after the earthquake affect this process adversely as well. Losing time due to collection of redundant information is another factor putting a strain for the technical team during the damage assessment works. Damage assessment teams should move as fast as possible and reach a maximum number of buildings in minimum time especially in major earthquakes. Therefore, the data that will make the basis of the first damage assessment should be selected correctly. Damage assessment forms are formed with the help of these data, and damage assessment can be conducted rapidly with the help of these forms. Damage assessment forms are commonly used in the first postearthquake damage assessments. Generally, these forms are completed as a result of the surveys at the site, and then the final decision on the structure is achieved based on the evaluations in the office environment.

Today, tablets and smart phones are used in many industries as a means of accessing information in view of the development process of information technologies. Any desired information and results can be accessed rapidly and practically with the help of these devices. In addition, possible errors can be reduced to a minimum level by making these data available to other people. Transferring the earthquake damages to a web-based environment makes them possible. Therefore, damage assessment studies will be managed more effectively.

In this study, the first post-earthquake damage assessments in masonry buildings were transferred to a database electronically. A damage assessment form issued by the Republic of Turkey Prime Minister, Disaster and Emergency Management Presidency (AFAD) was used for masonry buildings. Four masonry buildings in the province of Bitlis that were exposed to October 23, 2011 Van earthquake were taken into consideration in this study. Damage assessments regarding the buildings surveyed were indicated. Later on, a damage assessment was conducted on these buildings with the help of the forms issued by AFAD. After this stage, the damage assessment forms issued by AFAD were transferred to the electronic database, and the damage assessments for these buildings were conducted electronically. The images of the masonry buildings surveyed were transferred to the database as well. Another objective of this study is to reveal the reasons of use and usability of these forms issued by AFAD. The damage grading of the masonry buildings with different damage levels was performed in this study.

The objective of the study is to enable that the first post-earthquake damage assessments are conducted more rapidly, practically and scientifically with the help of smart phones and tablets. The results achieved will be checked by making the information transferred to the database available to different users. These procedures can be carried out independently of the space. In addition, it is aimed to create a database on earthquake damages. Such a database will help to develop regulations regarding earthquake. 
In the first part of the study, information was given on why damage assessment forms should be used. Information was given on the properties of the masonry buildings in Bitlis province. Information was given on the damage assessment forms for the masonry buildings that are the basis of the study. In the next stage, structural analyses were conducted for five different masonry buildings surveyed. Damage grading was performed for each structure. The damage levels were identified by giving information on the algorithm created for the form used and transferring all the structures surveyed into this database.

\section{PROPERTIES OF MASONRY BUILDINGS IN THE STUDY AREA (ÇALISSMA ALANINDAKI YIĞMA YAPILARIN ÖZELLIKLERI)}

The emergence of masonry buildings built using different materials backs to very old dates. Generally, such structures on which local materials are used are known to receive no engineering services. Masonry buildings are built by the craftsmen and workers living in that region. The earthquake effect behaviour of these structures is quite low.

The affecting loads on masonry buildings are carried by load-bearing walls. The loads are transferred to the ground via load-bearing walls. These wall thicknesses are significantly larger than those of the reinforced-concrete structures. As the wall elements will have both partition and bearing properties, the thickness value is large. The inner and outer walls of the building are formed by piling local materials on top of another and by combining the same with the help of a fastening material. Masonry materials such as stone, adobe, brick etc. are used for the vertical bearing elements (walls and columns) of the masonry systems, and the dominant stress type in the system is pressure. Even if geometry of the bearing system is linear (e.g. pylon, arch), planar (e.g. wall) and volumetric (e.g. vault or dome), there are compressive forces that are transmitted in one direction from the top to the structural bearings. As seen, the bearing elements overlap with the partitioning or covering elements in the masonry systems. In masonry buildings, the compressive strength of the materials used is high, while the tensile strength is low. In this case, these elements that can be exposed to large compressive forces are nondurable against the bending and shear effects [7-11]. As a result of instability against the shear effect, the materials forming the wall may be subject to segregation of various levels depending on the loading status and the materials used. Therefore, when making calculations for shear stresses in such structures, the properties of the material used as fasteners and its behaviour with the wall material should be known well. The properties of masonry building vary depending on these properties.

The masonry buildings in the province of Bitlis are built from local stones obtained from stone quarries. The local stones are used after being subjected to a cutting operation without any machinery in the quarries and the relevant region. Thin joint mortars are used between the local stones. Generally, flat earth shelters are used as roofs. Construction works are generally carried out by local craftsmen and workers. Mortars were used between the ashlars obtained from the quarries located in the province of Bitlis. Wooden ceilings are used in all houses. Earth shelters are used as roofs. In general, wooden beams are primarily used in the construction of these shelters. In terms of aesthetics, timber covers are used on top surfaces of them. The earth that will form the roof is laid on top of this, and a material that is a mixture of 'seh' (local material) and salt is laid on top of it to provide insulation. Water canals called 'coratan' are used to ensure water drainage on the earth shelters. Stones called 'sal' are placed around the shelter so that the shelter has an aesthetic appearance [12-15]. Examples of Bitlis masonry houses are shown in Figure 1.
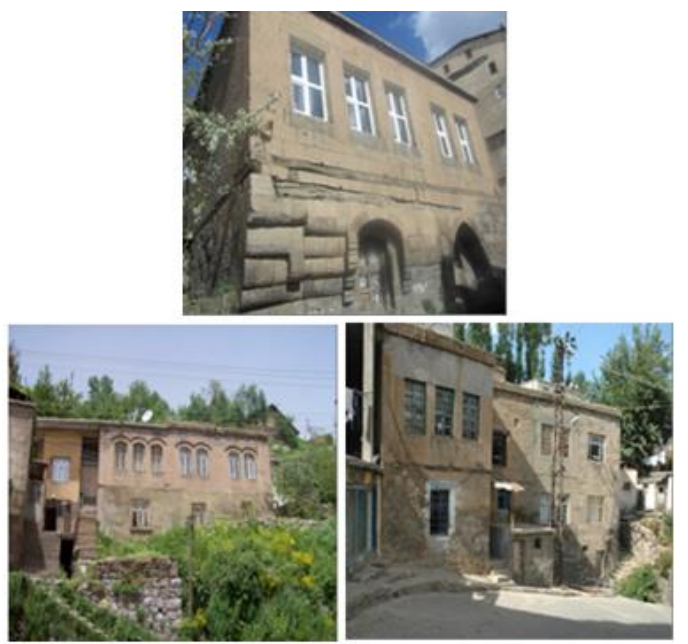

Figure 1. Masonry house examples in the region [13] (Bölgedeki ylğma ev örnekleri)

\section{DAMAGE ASSESSMENT IN MASONRY BUILDINGS (YIĞMA YAPILARDA HASAE DEĞERLENDIRMESI)}

Earthquakes frequently offer ascent to extraordinary harm to life and property. In line with this, most of the casualties are stem from the collapsed buildings. Therefore, building damage information 
investigation is the primary errand of earthquake damage information investigation.

After an earthquake, the damaged building data ought to be procured conveniently, and can be used to guide the effective implementation of the emergency rescue, which is essential for the decrease of losses [16-18] Seismic disaster management and mitigation require the foundation of a viable framework (or strategies) for evaluating spatial data and tremor peril [19]. The most critical aspect of damage analysis is related to the observations which are required to have a comprehensive and accurate building inventory and particularized damage data. It is highly possible to confront with fragmentary and restricted or accessible for single towns, districts or territories. Besides, the quality of the damage data can be insufficient. [20]. The damage data information of the structures and buildings are fundamental for search, rescue and auxiliary for reconstruction activities in the earthquake region. Therefore, building damage has been ranked in the field using damage scales [21].

The post-earthquake damage assessment in any structure is carried out to determine whether or not the building will be used immediately or whether repair and strengthening is required. To this end, all kinds of information on the structure is required. This process can be very complicated. Accurate identification of the damage classes of the buildings will positively affect losses of life and property in a possible second earthquake [22].

The fact that redundant information requests in the old forms used during the damage assessment slow down the work teams was more evident in the 2011 Van earthquake. Having initiated a study in 2012 in line with the requests of technical personnel at the site, the Disaster and Emergency Management Presidency (AFAD) issued the damage assessment forms for reinforced-concrete and masonry buildings, which are based on scientific data, aim to eliminate the use of opinions and were simplified from redundant information. In these new forms, it was aimed to ensure that the result is evaluated on-site or during the office work after the information on the structure is obtained.

In this study, the damage assessment forms issued by AFAD in order to determine the damage levels in the masonry buildings were used [23-24]. There are numerous masonry buildings that are widely used in rural areas of Turkey. Therefore, the location of the masonry buildings is very important in terms of seismicity. Firstly, detailed information on the form issued for the masonry buildings was provided in the study. The post-earthquake damage assessment can be performed systematically through these forms. After the earthquake disaster, the damage assessment form was used for the masonry buildings surveyed in the study. The damage estimation flow of these forms is specified in Figure 2. The process flow is filled separately for each masonry building to be surveyed.

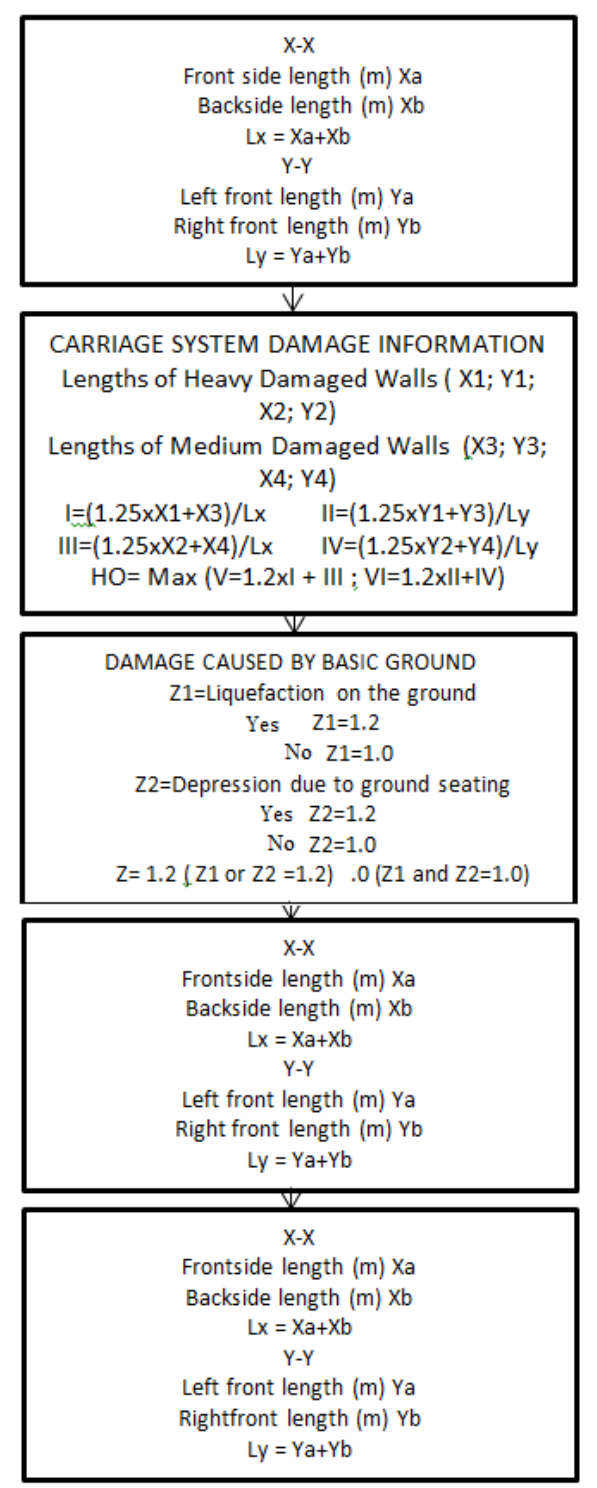

Figure 2. Post-earthquake damage assessment flowchart for masonry buildings (Ylğma yapılarda deprem sonrası hasar değerlendirme akış şeması)

It is determined whether or not to use these forms by performing damage estimation grading in the buildings. Statistical data on the earthquake are obtained. More effective performance of the necessary post-earthquake planning and the vital activities sustainment processes is directly related to the accurate completion of these forms. The 
earthquake zones can be determined more realistically by processing the data obtained from the damage assessment forms onto maps [23-24].

The personnel that will fill the earthquake damage form should be trained on how to complete the form. As a result of this process, the field works will be faster and more reliable. Generally, the success of data collection significantly depends on this preparation process. Otherwise, the field works need to be repeated in order to collect data.

It is important to issue the information form in a way to be evaluated by computer. Thus, a result can be got in a short time, and depending on the damage classes, results can be obtained in forms of graphics by evaluating the information according to the availability of the building and the residential areas. Furthermore, the relations between the loss of life that is the most important issue in the earthquake and the damage level in buildings and the load-bearing system can be obtained. Images of the buildings that are subject to damage assessment are transferred to the web base as well.

\section{INVESTIGATED MASONRY BUILDINGS (INCELENMIŞ YIĞMA BINALAR)}

On 23.10.2011, at 13:41 local time, a Mw: 7.2 earthquake occurred around the province of Van. The earthquake was felt in the residential areas, especially in the province of Van and Erciş district of Van, in the Van Lake Basin, where the seismicity element is continuously ignored. The largest losses in terms of structural damages were suffered in Van and Erciş. The province of Bitlis and its districts follow these regions areas in terms of places where damages are observed widely [25-27]. Four masonry buildings that are located in the province of Bitlis and were subjected to the October 23, 2011 Van earthquake were taken as samples. The damages related to the buildings surveyed were specified. Later on, a damage assessment was conducted on these buildings with the help of the forms issued by AFAD.

\subsection{Building-1 (Bina-1)}

The building was built of two stoires from the local stones. The ground story is used as a shed, while the top story is used as a residence. Houses built in this style are widespread in the rural areas of Bitlis. In addition to the structure, there is a porch built from briquette made of pumice, which is widely encountered in this region. The structure was built in the form of a rectangular with a size of $6.20 \times 8.20 \mathrm{~m}$. Middy mortar made of soil was used on the junctions of walls. There is a heavy load on the structure due to earth shelter. On the load-bearing wall placed at the rear front of the structure, there were some segregations larger than $2 \mathrm{~cm}$ and some stones were replaced. There were some segregations larger than 2 $\mathrm{cm}$ on the left side of the structure and those larger than $1 \mathrm{~cm}$ on the facade. The fact that fixation of the floor and shelter to the walls is insufficient is one of the reasons of the damage. The damages on this building are given in Figure 3.

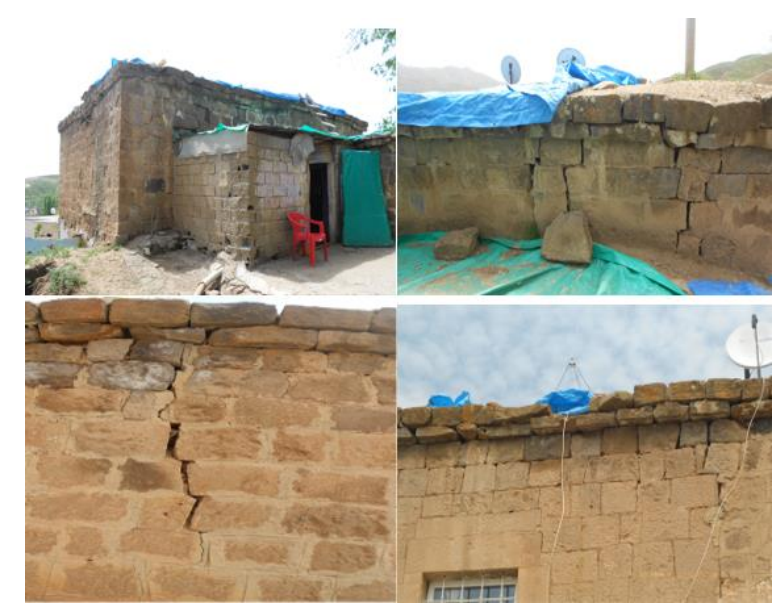

Figure. 3. Damages on masonry building-1 (1.Bina hasarlarl)

The lengths of the boundary wall of the building-1 surveyed that make the basis of the damage assessment are given in Table 1.

Table 1 . The lengths of the boundary wall of the masonry building -1 (Ylğma binanın sinır duvar uzunlukları)

\begin{tabular}{|c|c|c|c|}
\hline \multicolumn{3}{|c|}{ LENGTHS OF BOUNDARY WALLS } \\
\hline $\begin{array}{c}\text { Length of the building's boundary walls (excluding door-window } \\
\text { openings) on the floor with the largest damage (m) }\end{array}$ \\
\hline \multicolumn{2}{|c|}{$\begin{array}{c}\text { X-X direction } \\
\text { building facade and rear } \\
\text { front }\end{array}$} & \multicolumn{2}{|c|}{$\begin{array}{c}\text { Y-Y direction building left and } \\
\text { right fronts }\end{array}$} \\
\hline $\begin{array}{c}\text { Length of } \\
\text { facade (m) }\end{array}$ & 5.90 & $\begin{array}{c}\text { Length of left front } \\
(\mathrm{m})\end{array}$ & 6.20 \\
\hline $\begin{array}{c}\text { Length of rear } \\
\text { front (m) }\end{array}$ & 8.20 & $\begin{array}{c}\text { Length of right } \\
\text { front (m) }\end{array}$ & 6.20 \\
\hline $\begin{array}{c}\text { Total net length, } \\
\mathrm{L}_{\mathrm{X}}(\mathrm{m})\end{array}$ & 14.10 & $\begin{array}{c}\text { Total net length, } \mathrm{L}_{\mathrm{Y}} \\
(\mathrm{m})\end{array}$ & 12.40 \\
\hline
\end{tabular}

After the damage information of the load-bearing system is obtained, the damage condition caused depending on the basement ground should be determined. The damage condition of the ground belonging to the building-1 is specified in Table 2 . No cracks caused by ground subsidence were observed either at the liquefaction or the plinth level in the foundation soil of the building surveyed. 
Table 2. Ground damage status for building-1 (Bina 1 için Zemin hasar durumu)

\begin{tabular}{|c|c|c|c|}
\hline \multicolumn{4}{|c|}{$\begin{array}{l}\text { DAMAGES STATUS ACCORDING TO BASEMENT } \\
\text { GROUND CONDTION }\end{array}$} \\
\hline \multicolumn{2}{|c|}{$\begin{array}{l}\text { Z1- Ground collapse } \\
\text { (liquefaction) }\end{array}$} & \multicolumn{2}{|c|}{$\begin{array}{l}\text { Z2- Cracks caused by ground } \\
\text { subsidence on the level of plinth } \\
\text { level in the foundation. }\end{array}$} \\
\hline $\begin{array}{l}\text { No } \\
(\mathrm{Z}=1)\end{array}$ & $\begin{array}{c}\text { Yes } \\
(\mathrm{Z}=1.2)\end{array}$ & $\begin{array}{c}\text { No } \\
(\mathrm{Z}=1)\end{array}$ & $\begin{array}{c}\text { Yes } \\
(\mathrm{Z}=1.2)\end{array}$ \\
\hline
\end{tabular}

In the following stage, the damage conditions of the non-structural system elements on the building are determined. These values for building-1 were given in Table 3. The damage information of the load-bearing system can be calculated using the lengths of the boundary walls obtained. The damage information of the load-bearing system of the masonry building- 1 is calculated in Table 4.

Table 3. Status of damage for non-structural elements for building-1(Bina 1 için yapısal olmayan elemanlarda hasar durumu)

\begin{tabular}{|c|c|c|c|c|}
\hline \multicolumn{5}{|c|}{ STATUS OF DAMAGE FOR NON-STRUCTURAL ELEMENTS FOR BUILDING-1 } \\
\hline $\begin{array}{c}\mathrm{N} 1 \\
\text { Gamble wall } \\
\text { damage }\end{array}$ & $\begin{array}{l}\text { N2 Staircase } \\
\text { damage }\end{array}$ & $\begin{array}{c}\mathrm{N} 3-\text { Flue or } \\
\text { parapet damage }\end{array}$ & $\begin{array}{c}\mathrm{N} 4 \text { - Shear } \\
\text { damage at infill } \\
\text { walls }\end{array}$ & $\begin{array}{l}\text { Additive to damage } \\
\text { (HK) }\end{array}$ \\
\hline YES 1; NO 0 & YES 1; NO 0 & YES 1; NO 0 & YES 1; NO 0 & $\begin{array}{c}0.025 *(\mathrm{~N} 1+\mathrm{N} 2+ \\
\mathrm{N} 3+ \\
\mathrm{N} 4) \\
\end{array}$ \\
\hline $\mathrm{NO}$ & $\mathrm{NO}$ & $\mathrm{NO}$ & NO & HK \\
\hline $\mathrm{N} 1=0$ & $\mathrm{~N} 2=0$ & $\mathrm{~N} 3=0$ & $\mathrm{~N} 4=0$ & Hh \\
\hline
\end{tabular}

With the help of this information obtained, damage rating for this building performed. Damage rating for the building- 1 is shown in Table 5

\subsection{Building-2 (Bina-2)}

The building was built of single story from the local stones. The building is used as residence. The building was built in the form of a rectangular with a size of $11.50 \mathrm{~m} \times 8.50 \mathrm{~m}$. A heavier load was created on the building by adding a roof on the earth shelter. There were some segregations larger than $2 \mathrm{~cm}$ at the corner junction points of the rear front of the building. The fractures and cracks in the right flank front were measured to be larger than $1 \mathrm{~cm}$. While on the left flank front, there were fractures and cracks larger than $2 \mathrm{~cm}$. There are local wall damages ranging from 0.5 to $1.5 \mathrm{~cm}$ in the middle partition walls within the building. Images of the building and damages are shown in Figure 4

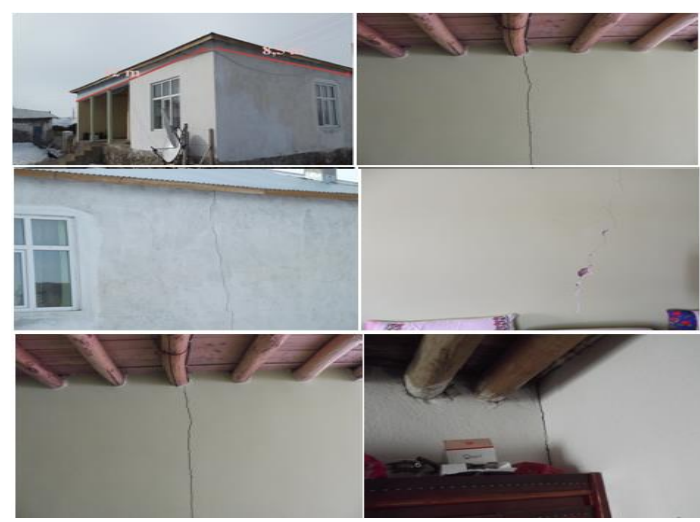

Figure 4. Damages on masonry building-2 (2.Yı̆̆ma binadaki hasar durumu)

\subsection{Building-3 (Bina-3)}

The building was built of single floor from the local stones. The building is used as residence. The building was built in the form of a rectangular with a size of $12.00 \mathrm{~m} \times 8.50 \mathrm{~m}$. A heavier load was created on the building by adding a roof on the earth shelter. Damages ranging from 0.5 to $1 \mathrm{~cm}$ were formed on the walls that make up the middle partitions of the building, while there are moderate damages ranging from 0.5 to $2 \mathrm{~cm}$ were formed on the outer wall. Images of the building and damages are shown in Figure 5.

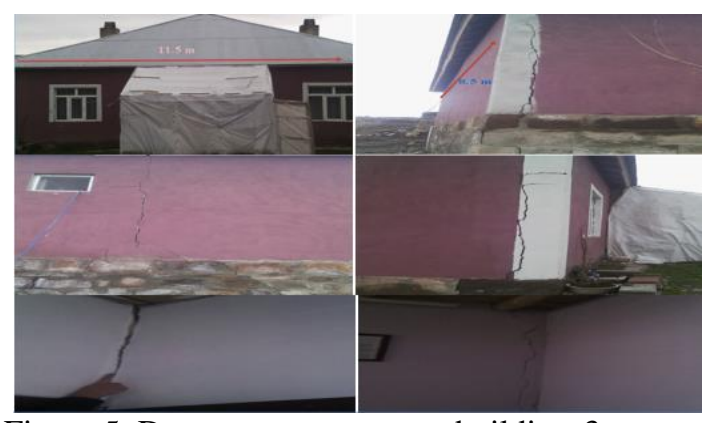

Figure 5. Damages on masonry building-3 (3. Yı̆̆ma binadaki hasar durumu)

\subsection{Building-4 (Bina-4)}

The building was built of single floor from the local stones. The building is used as residence. The building was built in the form of a rectangular with a size of $12.00 \mathrm{~m} \times 7.0 \mathrm{~m}$. A heavier load was created on the building by adding a roof on the earth shelter. Damages ranging from 0.5 to $1 \mathrm{~cm}$ were formed on the walls that make up the middle partitions of the building, while there are trivial damages ranging from 0.5 to $1 \mathrm{~cm}$ were formed on the outer wall. Images of the building and damages are shown in Figure 6. 
Table 4. Information on the damages on the load-bearing system of the building-1 (Binanin tașlyılcı sistemindeki hasarlara ilișkin bilgiler)

\section{DAMAGE INFORMATION OF THE LOAD-BEARING SYSTEM}

This will be completed on the floor, where the largest damage is observed.

For the surveyed boundary walls, the most severe damage condition among the following articles will be taken as basis.

\begin{tabular}{|c|c|c|c|c|c|}
\hline & \multicolumn{2}{|c|}{$\begin{array}{l}\text { The corner and the } \\
\text { wall concurrent to the corner }\end{array}$} & \multicolumn{2}{|c|}{$\begin{array}{l}\text { The walls in } \\
\text { the middle of the fronts }\end{array}$} \\
\hline & & $\mathrm{X}-\mathrm{X}(\mathrm{m})$ & Y-Y (m) & $\mathrm{X}-\mathrm{X}(\mathrm{m})$ & $\mathrm{Y}-\mathrm{Y}(\mathrm{m})$ \\
\hline \multirow[t]{2}{*}{$\begin{array}{l}3.1 . \\
\text { Lengths } \\
\text { of the } \\
\text { Heavily } \\
\text { Damaged } \\
\text { Walls }\end{array}$} & \begin{tabular}{|l|}
$\begin{array}{l}\text { Damage } \\
\text { condition } \\
\text { observed }\end{array}$ \\
Segregation \\
of out-of- \\
plane \\
collapsed \\
wall and \\
Concurrent \\
walls \\
( $\geq 20 \mathrm{~mm}) ;$ \\
diagonal/X \\
cracks on \\
Corner/Fro \\
nt walls \\
( $\geq 10 \mathrm{~mm}) ;$ \\
\end{tabular} & 5.90 & 6.20 & 0 & 0 \\
\hline & & $\mathrm{X} 1=5.90(\mathrm{~m})$ & $\mathrm{Y} 1=6.20(\mathrm{~m})$ & $\mathrm{X} 2=(\mathrm{m})$ & $\mathrm{Y} 2=(\mathrm{m})$ \\
\hline $\begin{array}{l}3.1 . \\
\text { Lengths } \\
\text { of the } \\
\text { Moderatel } \\
\text { y } \\
\text { Damaged } \\
\text { Walls }\end{array}$ & 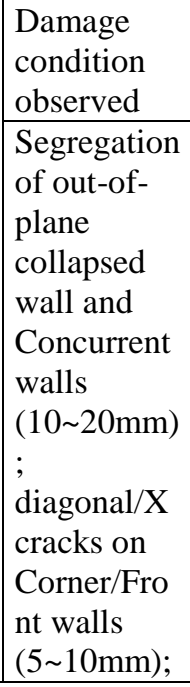 & 5.90 & 0 & 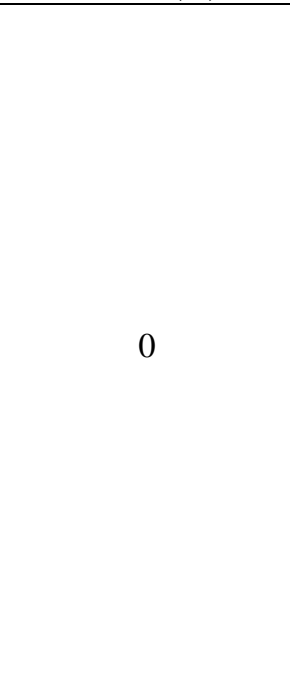 & 0 \\
\hline & & $\mathrm{X} 3=5.90(\mathrm{~m})$ & $\mathrm{Y} 3=(\mathrm{m})$ & $\mathrm{X} 4=(\mathrm{m})$ & $\mathrm{Y} 4=(\mathrm{m})$ \\
\hline \multirow{2}{*}{\multicolumn{2}{|c|}{$\begin{array}{l}\text { 3.3. Length Ratio of } \\
\text { Damaged Wall }\end{array}$}} & $\begin{array}{c}\mathrm{I}=(1.25 \mathrm{xX} 1+\mathrm{X} 3) / \\
\mathrm{Lx}\end{array}$ & $\begin{array}{c}\mathrm{II}=(1.25 \mathrm{xY} 1+\mathrm{Y} 3) / \\
\mathrm{Ly}\end{array}$ & $\begin{array}{c}\mathrm{III}=(1.25 \times \mathrm{X} 2+\mathrm{X} 4) / \\
\mathrm{Lx}\end{array}$ & $\begin{array}{c}\mathrm{IV}=(1.25 \mathrm{xY} 2+\mathrm{Y} 4) / \\
\mathrm{Ly}\end{array}$ \\
\hline & & 0.523 & 0.625 & 0 & 0 \\
\hline Total & & $\mathrm{V}=1.2$ & $\mathrm{I}+\mathrm{III}=0.623$ & $\mathrm{VI}=1.2 \mathrm{xII}+$ & $\mathrm{V}=0.75$ \\
\hline \multicolumn{6}{|c|}{ DAMAGE INFORMATION OF THE LOAD-BEARING SYSTEM } \\
\hline \multicolumn{6}{|c|}{$\begin{array}{l}\text { This will be completed on the floor, where the largest damage is observed. } \\
\text { For the surveyed boundary walls, } \\
\text { the most severe damage condition among the following articles will be taken as basis. }\end{array}$} \\
\hline & & \multicolumn{2}{|c|}{$\begin{array}{l}\text { The corner and the } \\
\text { wall concurrent to the corner }\end{array}$} & \multicolumn{2}{|c|}{$\begin{array}{l}\text { The walls in } \\
\text { the middle of the fronts }\end{array}$} \\
\hline & & $\mathrm{X}-\mathrm{X}(\mathrm{m})$ & $\mathrm{Y}-\mathrm{Y}(\mathrm{m})$ & $\mathrm{X}-\mathrm{X}(\mathrm{m})$ & $\mathrm{Y}-\mathrm{Y}(\mathrm{m})$ \\
\hline
\end{tabular}




\begin{tabular}{|c|c|c|c|c|c|}
\hline \multirow[t]{2}{*}{$\begin{array}{l}3.1 . \\
\text { Lengths } \\
\text { of the } \\
\text { Heavily } \\
\text { Damaged } \\
\text { Walls }\end{array}$} & \begin{tabular}{|l|}
$\begin{array}{l}\text { Damage } \\
\text { condition } \\
\text { observed }\end{array}$ \\
Segregation \\
of out-of- \\
plane \\
collapsed \\
wall and \\
Concurrent \\
walls \\
( $\geq 20 \mathrm{~mm}) ;$ \\
diagonal/X \\
cracks on \\
Corner/Fro \\
nt walls \\
( $\geq 10 \mathrm{~mm}) ;$
\end{tabular} & 5.90 & 6.20 & 0 & 0 \\
\hline & & $\mathrm{X} 1=5.90(\mathrm{~m})$ & $\mathrm{Y} 1=6.20(\mathrm{~m})$ & $\mathrm{X} 2=(\mathrm{m})$ & $\mathrm{Y} 2=(\mathrm{m})$ \\
\hline $\begin{array}{l}3.1 . \\
\text { Lengths } \\
\text { of the } \\
\text { Moderatel } \\
\text { y } \\
\text { Damaged } \\
\text { Walls }\end{array}$ & \begin{tabular}{|l|}
$\begin{array}{l}\text { Damage } \\
\text { condition } \\
\text { observed }\end{array}$ \\
Segregation \\
of out-of- \\
plane \\
collapsed \\
wall and \\
Concurrent \\
walls \\
$(10 \sim 20 \mathrm{~mm})$ \\
$;$ \\
diagonal/X \\
cracks on \\
Corner/Fro \\
nt walls \\
(5 10mm);
\end{tabular} & 5.90 & 0 & 0 & 0 \\
\hline \multirow{3}{*}{\multicolumn{2}{|c|}{$\begin{array}{l}\text { 3.3. Length Ratio of } \\
\text { Damaged Wall }\end{array}$}} & $\mathrm{X} 3=5.90(\mathrm{~m})$ & $\mathrm{Y} 3=(\mathrm{m})$ & $\mathrm{X} 4=(\mathrm{m})$ & $\mathrm{Y} 4=(\mathrm{m})$ \\
\hline & & $\begin{array}{c}\mathrm{I}=(1.25 \mathrm{xX} 1+\mathrm{X} 3) / \\
\mathrm{Lx}\end{array}$ & $\begin{array}{c}\mathrm{II}=(1.25 \mathrm{xY} 1+\mathrm{Y} 3) / \\
\mathrm{Ly}\end{array}$ & $\begin{array}{c}\mathrm{III}=(1.25 \mathrm{xX} 2+\mathrm{X} 4) / \\
\mathrm{Lx}\end{array}$ & $\begin{array}{c}\mathrm{IV}=(1.25 \times \mathrm{x} 2+\mathrm{Y} 4) \\
\mathrm{Ly}\end{array}$ \\
\hline & & 0.523 & 0.625 & 0 & 0 \\
\hline \multicolumn{2}{|l|}{ Total } & \multicolumn{2}{|c|}{$\mathrm{V}=1.2 \mathrm{xI}+\mathrm{III}=0.623$} & \multicolumn{2}{|c|}{$\mathrm{VI}=1.2 \mathrm{xII}+\mathrm{IV}=0.75$} \\
\hline
\end{tabular}

Table 5. Damaged evaluation for building-1 (1.Binaya ait hasar değerlendirme) STATUS OF DAMAGE FOR NON-STRUCTURAL ELEMENTS FOR BUILDING-1

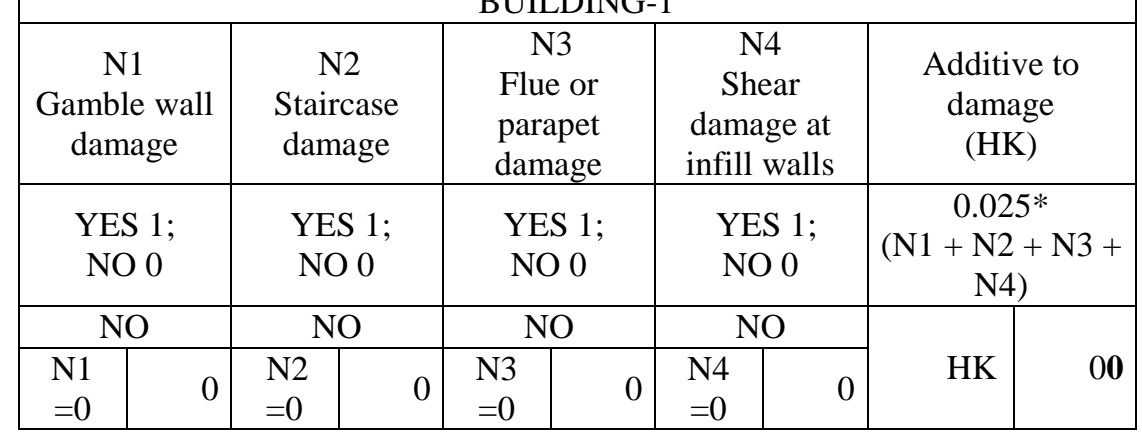




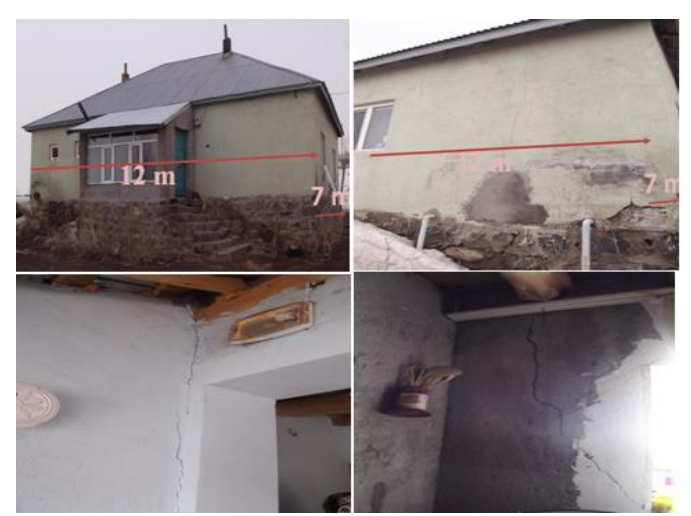

Figure 6. Damages on masonry building-4 (4.Yı̆̆ma binaya ait hasarlar)

After information on the buildings and damages to the buildings was given, the damage assessment rating form was completed separately for each building. The damage rating procedure for four buildings considered in the study is shown in Table 6. As a result of the evaluation, two of them were determined to be moderately damaged, one to be heavily damaged, the other one to be slihgtly damaged. The damage assessments will be controlled by different people more easily with the help of these forms. The values obtained from the surveys conducted on the site will enable to get results in a healthy and rapid in a more comfortable environment. Completing the damage assessment forms properly is directly proportionate to the trainings to be provided for the technical staff to complete the form. The damage rating on these forms will have a more realistic and scientific base thanks to the trainings to be provided. These forms that used to be complex in previous years were made more usable following the 2011 Van earthquakes.

Table 6. Damage evaluation of investigated buildings (Incelenen binalara ait hasar değerlendirme)

\begin{tabular}{|c|c|c|c|c|c|}
\hline \multirow{2}{*}{\multicolumn{2}{|c|}{$\begin{array}{l}\text { BUILDING NO } \\
\text { VALUE }\end{array}$}} & \multirow[t]{2}{*}{1} & \multirow[t]{2}{*}{2} & \multirow[t]{2}{*}{3} & \multirow[t]{2}{*}{4} \\
\hline & & & & & \\
\hline \multirow{3}{*}{$\underset{x}{x}$} & Facade (m) & 5.90 & 8.00 & 9.75 & 9.80 \\
\hline & Rear front $(\mathrm{m})$ & 8.20 & 10.60 & 10.80 & 10.50 \\
\hline & Lx & 14.10 & 18.60 & 20.55 & 20.30 \\
\hline \multirow{3}{*}{$\lambda$} & Left (m) & 6.20 & 7.70 & 7.20 & 5.00 \\
\hline & Right (m) & 6.20 & 8.50 & 7.70 & 6.00 \\
\hline & Ly & 12.40 & 16.20 & 14.90 & 11.00 \\
\hline \multicolumn{2}{|r|}{$\mathrm{X} 1$} & 5.90 & 11.50 & 0 & 0 \\
\hline \multicolumn{2}{|r|}{$\mathrm{Y} 1$} & 6.20 & 8.50 & 0 & 0 \\
\hline \multicolumn{2}{|r|}{$\mathrm{X} 2$} & 0 & 0 & 0 & 0 \\
\hline \multicolumn{2}{|r|}{ Y2 } & 0 & 4.20 & 0 & 0 \\
\hline \multicolumn{2}{|r|}{$\mathrm{X} 3$} & 0 & 3.80 & 4.20 & 7.00 \\
\hline \multicolumn{2}{|r|}{$\mathrm{Y3}$} & 0 & 0 & 4.00 & 0 \\
\hline \multicolumn{2}{|r|}{$\mathrm{X} 4$} & 0 & 0 & 4.20 & 0 \\
\hline \multicolumn{2}{|r|}{ Y4 } & 0 & 0 & 3.60 & 3.8 \\
\hline \multicolumn{2}{|r|}{ I } & 0.523 & 0.98 & 0.204 & 0.345 \\
\hline \multicolumn{2}{|r|}{ II } & 0.625 & 0.66 & 0.268 & 0 \\
\hline \multicolumn{2}{|r|}{ III } & 0 & 0 & 0.204 & 0 \\
\hline \multicolumn{2}{|r|}{ IV } & 0 & 0.3 & 0.241 & 0.345 \\
\hline \multicolumn{2}{|r|}{$\mathrm{V}$} & 0.623 & 1.14 & 0.448 & 0345 \\
\hline \multicolumn{2}{|r|}{ VI } & 0.75 & 1.09 & 0.562 & 0.345 \\
\hline \multicolumn{2}{|r|}{$\mathrm{Z1}$} & 1 & 1 & 1 & 1 \\
\hline \multicolumn{2}{|r|}{$\mathrm{Z} 2$} & 1 & 1.2 & 1 & 1 \\
\hline \multicolumn{2}{|r|}{ N1 } & 0 & 0 & 0 & 0 \\
\hline \multicolumn{2}{|r|}{$\mathrm{N} 2$} & 0 & 0 & 0 & 0 \\
\hline \multicolumn{2}{|r|}{ N3 } & 0 & 0 & 0 & 0 \\
\hline \multicolumn{2}{|r|}{ N4 } & 0 & 1 & 0 & 0 \\
\hline \multicolumn{2}{|r|}{$\mathrm{HK}$} & 0 & 0.025 & 0 & 0 \\
\hline \multicolumn{2}{|r|}{$\mathrm{HO}$} & 0.75 & 1.14 & 0.562 & 0.345 \\
\hline \multicolumn{2}{|r|}{ THO } & 0.75 & 1.393 & 0.562 & 0.345 \\
\hline & THO x $100(\%)$ & 75 & 130 & 56.20 & 34.50 \\
\hline & AGE STATUS & MEDIUM & HEAVY & MEDIUM & SLIGHTLY \\
\hline
\end{tabular}




\section{WEB-BASED ASSESSMENT (WEB TABANLI DE ĞERLENDIRME)}

As a result of the developments in the information technology, local governments started to collect, store and process the positional data they use for their own service areas in the computer environment and to produce new information as a result of analysis. The desire to use information technologies in evaluation and monitoring systems is increasing day by day. It is because the mobile devices are spread and increased in use since they are smaller, are able to work as wireless and have high memory capacity. These elements require mobile devices to be used in many areas such as environmental control, monitoring of health services and security, transportation and automation[28-39].

Structural control has a wide area that combining automatic control and structural engineering areas using a variety of applications from aerospace and mechanical engineering to infrastructure systems such as building. Technological developments in seismic instrumentation enable the application of digital communication and computer technologies, real-time early warning and rapid damage assessment systems [40-41]. The form, which was formed after a natural disaster in masonry buildings, was turned into an internet form and transferred to the digital media so that it can be evaluated more rapidly.

A web page was created and each field of the form on this page was associated with a database so that the form can work effectively. In this way, it became possible to make an analysis and assessment for the data entered. It was enabled to create plenty of statistical information by forming a wide database. The web-based post-disaster rapid assessment application developed for the masonry buildings consists of a user interface and a database to which this interface is associated. The interface program was developed in php language, while MySQL language was used for the database. Web-based software is expected to have a flexible, rapid and reliable structure. This type of software should provide the user with ease of programming as well as a flexible and secure structure. These properties specified can be realized effectively using php-based MySQL database.

For the web-based software, a restriction process is also performed for the data entered by the user. In this case and in the event that the user enters incorrect or inadequate data, the system automatically sends a warning message to the user. The most accurate result is achieved with mathematical and logical expressions created in background by entering the data successfully into the rapid assessment form and the coding created, and these values are automatically registered The association belonging to the assessment form used in the database registration process is presented in Figure 7. The flow diagram of the software is presented in Appendix-1.

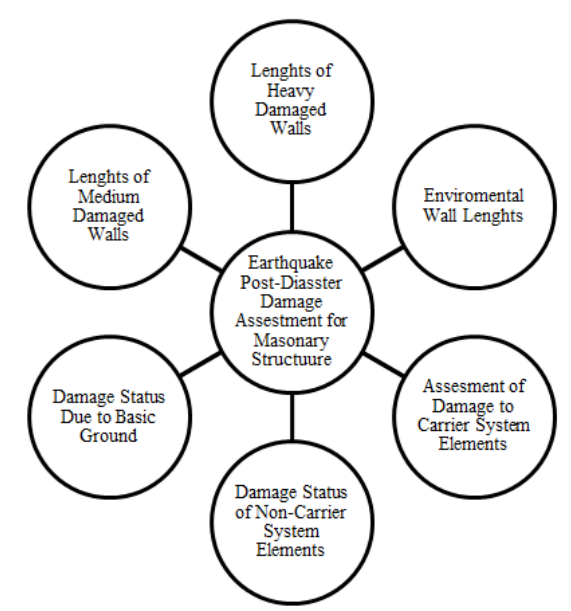

Figure 7. Database evaluation form-data relationship (Veri tabanı değerlendirme form-veri ilişkisi)

Each building was assigned a value called "Building ID" so that the database registration process can be realized any desired data can be obtained from the database. This is a value belonging to the registered building, and in this way, it was prevented to register another structure with the same value. In addition, each building entered was given a sequence number. The data-interface-database association of the developed web-based software is presented in Figure 8.

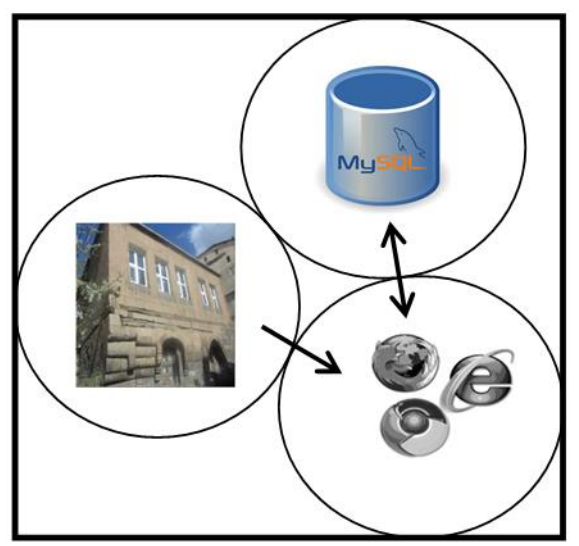

Figure 8. Algorithm of software system operation (Yazılım geliștirme algoritması)

A site with the address smarthomes.com, which is associated with php-based and MySQL database, was created in order to assess and determine the post- 
earthquake damages for the masonry buildings. The post-earthquake assessment of the wooden buildings is carried out on the site, and each building is assessed according to its ID number. The data entered for the building are assessed in two different situations. Firstly, in case of any collapse in the building, the data of the building are registered in the database, and the registration is performed writing "COLLAPSED" in the conclusion section in the database, without any need for data entry. The image for this case is presented in Figures 9 and 10. In Figure 10, the employee logging in to enter the site is asked "Is there any collapse?" If the answer is affirmative, the process is completed by entering data into the fields indicated in Figure 10. At the end of this process, the information that a building collapsed is registered.

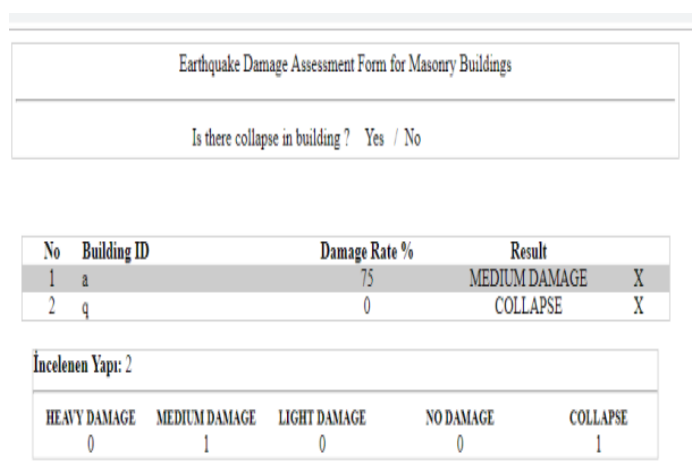

Figure 9. Home page for damage assessment (Hasar değerlendirme ana sayfa)

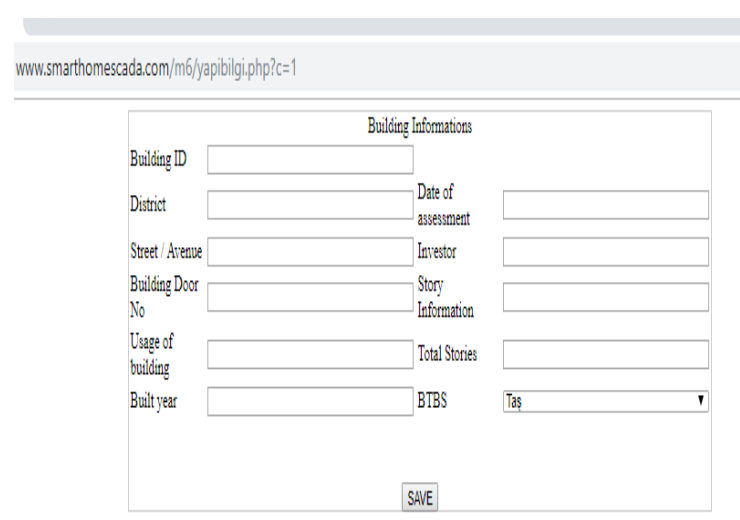

Figure 10. Data entry for collapse (Çökme veri girişi)

The other situation is that there is some collapse in the building. When the question "Is there any collapse?" in Figure 9 is answered negatively, the form indicated in Figure 11 is opened. In case of data entry to the required fields in Figure 11 and upon the completion of the registration process of these data, the collapse condition is formed by the program and the database registration process is completed. Depending on the calculated data, it is assessed as heavy damage, moderate damage, slightly damage, no damage or collapse and subjected to assessment as statistical data.

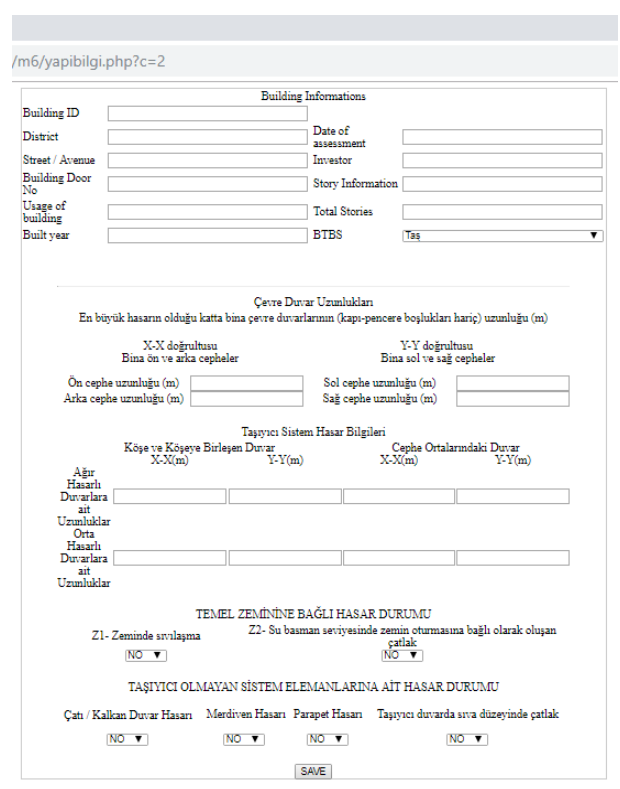

Figure 11. Data entry screen in case of non-collapse (Çökmeme durumu için veri giriş̧i)

As shown in Figure 11, there is information on the process result of the buildings, of which database registration process was completed by the user. In addition, the statistical information is presented in the same field depending on the damage status of the wooden buildings entered. As the employees carrying out different surveys use the same database, it prevents assessment of a building by different people and enables the process to be assessed more rapidly and transparently. As the developed web page has a structure that can be used not just for one region or one person but by everyone and for each region, it is expected that the number of users will increase on a global scale. The result screen of earthquake damage evaluation is presented in Figure 12.

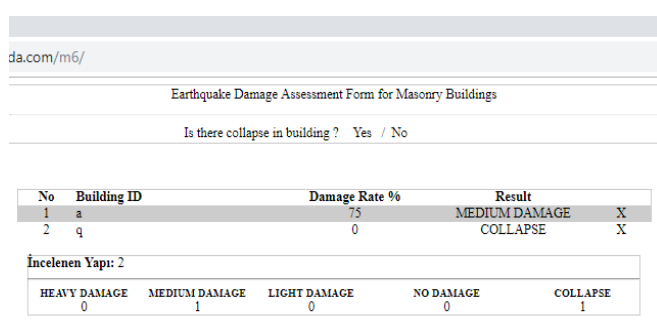

Fig. 12. Result screen of earthquake damage evaluation for masonry buildings (Ylğma yapıların için hasar değerlendirme sonuç ekranı) 


\section{RESULTS (SONUÇLAR)}

The persons that will complete the earthquake damage form should be trained on how to complete the form. As a result of this process, the field works will be faster and more reliable. Generally, the success of data collection significantly depends on this preparation process. Otherwise, the field works need to be repeated in order to collect data.

It is important to issue the information form in a way to be evaluated by computer. Thus, a result can be got in a short time, and depending on the damage level, results can be obtained in forms of graphics by evaluating the information according to the availability of the building and the residential areas. Furthermore, the relations between the loss of life that is the most important issue in the earthquake and the damage level in buildings and the load-bearing system can be obtained. These forms issued by AFAD created a scientific basis for the assessment of damages emerging on buildings.

In this study, four masonry buildings were selected in order to reveal the effects of the damages caused by the Van earthquake in the province of Bitlis. The damage assessment forms were completed separately for each building, and the damage levels were determined. This study has an important place in terms of revealing the importance of masonry buildings, which are widely used in rural areas of Anatolia.

This study provides information on the construction techniques of masonry buildings in Bitlis. In this context, horizontal beams should be used to ensure the connection between the walls in the construction of earth shelters used on these houses. Heavy loads caused by earth shelters increase the damages in the structure.

In this context, the design principles of the masonry buildings included in the Turkish Building Earthquake Code should be considered. In addition, the project design process for such structures should be placed on a legal basis. It should be a legal obligation that such structures are provided engineering services. Thus, damages and losses that may occur in the buildings with engineering services will be kept at lower levels.

In addition, it will make sense to develop province-based standard masonry building projects for each province. Construction technology and local materials may vary in each province. It will be an important move to minimize wall damages to select accurately the joining tools to be used especially on the walls.

The damage assessment processes of masonry buildings, which were exposed to earthquake effect and constitute a large part of the buildings in rural areas, were transferred to the electronic media, and damage grading was carried out electronically. With the help of this environment created, information that need to be received or required from different institutions was gathered via internet in MYSQL database operating very rapidly.

Besides creating a database for the masonry buildings, the earthquake-exposed masonry buildings will be transferred to the database thanks to this study. Thanks to the information obtained, the earthquake zones will be determined more realistically as well as and it will enable to develop construction principles related to masonry buildings. Such studies can be used as a supporting tool for the post-earthquake decision makers. Rapid and practical solutions are required to sustain the post-earthquake social life. This study will be very efficient in meeting this kind of deficit.

In this study, local administrations and the relevant public institutions and organizations will be able to directly access the earthquake-exposed building stock and data, and if they desire, will ensure use of these data in the electronic media. Damage assessment in buildings, classification of the same and decision making process for use will be performed in a controlled manner thanks to the post-earthquake data related to the buildings.

In the system installed, all data can be defined, stored, processed and analysed as associated in an efficient and detailed way in a single database. In this way, time and finance can be saved in the decision making and implementation processes, and an institutional resource planning infrastructure can be formed. Thanks to the method used in the study, a knowledge-based management process with a consistent structure information system infrastructure and a knowledge-based strategic plan can be used effectively. In addition, it will be possible to access the data of the earthquake-exposed building stock as independently of the space. This study can be expanded with new modules. Its sustainability can be ensured easily.

The fact that the earthquake-exposed building stock is large results in that evaluations related to such buildings are not very realistic due to lack of time and technical staff. Rapid damage assessment methods are 
required so that these evaluations provide scientifically healthy results. Pursuant to this requirement, AFAD developed the damage assessment forms. It is possible to identify some parameters that will affect the behaviour of the building during the earthquake without getting into the building, and in part, within the building. The damage levels of the buildings are identified by this calculation.

\section{CONFLICTS OF INTEREST}

The authors reported no potential conflict of interest

\section{REFERENCES (KAYNAKLAR)}

[1] M.F Işık, E Işık, M.A Bülbül, ve İ.B Karaşin, "Doğal afet sonrası hasarların web tabanlı değerlendirilmesi", International Conference on Advanced Engineering Technologies, Bayburt, Türkiye, vol.21, pp. 21-23, September 2017.

[2] Hadzima-Nyarko, Marijana, G. Pavic, and M. Lešić, "Seismic vulnerability of old confined masonry buildings in Osijek, Croatia", Earthquakes and Structures, vol. 11, no. 4, pp.629-648, 2016, doi: 10.12989/eas.2016.11.4.000

[3] E. Işık, "Consistency of the rapid assessment method for reinforced concrete buildings", Earthquakes and Structures, vol. 11, no. 5, pp.873885. 2016. doi: 0.12989/eas.2016.11.5.873

[4] M. B. Anoop, K. B. Rao, "Seismic damage estimation of reinforced concrete framed structures affected by chloride-induced corrosion", Earthquakes and Structures, vol. 9, no. 4, pp. 851-873. 2015. doi:10.12989/eas.2015.9.4.851

[5] T. K. Šipoš, M. Hadzima-Nyarko, "Rapid seismic risk assessment", International Journal of Disaster Risk Reduction, vol. 24, pp.348-360, 2017. doi: 10.1016/j.ijdrr.2017.06.025

[6] M. Hadzima-Nyarko, N.Ademović, G. Pavić, T. K. Šipoš, "Strengthening techniques for masonry structures of cultural heritage according to recent Croatian provisions", Earthquakes and Structures, vol. 15, no. 5, pp. 473, 2018, doi: 10.12989/eas.2018.15.5.473

[7] İ. F. Çırak, "Yığma Yapılarda Oluşan Hasarlar, Nedenleri ve Öneriler", SDU International Technologic Science, vol. 3, no. 2, pp.55-60, 2011.
[8] E. Işık , İ. Karaşin ve B. Eren, "Mevcut bir Yığma Yapının Farklı Hızlı Değerlendirme Yöntemleri ile Değerlendirilmesi", Dicle Üniversitesi Fen Bilimleri Enstitüsü Dergisii, vol. 5, no. 2, pp. 70-76, Jul. 2016.

[9] A. Karaşin, M.E.Öncü, "Çok katlı yığma binaların deprem güvenliklerinin değerlendirilmesi”. Doğu Anadolu Araştırmaları Dergisi, pp.63-68, 2009.

[10] A.Korkmaz, A.I. Çarhoğlu, A.V. Orhon A.Nuhoğlu, "Farklı yapısal malzeme özelliklerinin yığma yapı davranışına etkisi”, Nevşehir Bilim ve Teknoloji Dergisi, vol.3, no. 1, pp.69-78, 2014.

[11] M.Hadzima-Nyarko, D.Morić, G.Pavić, and V.Mišetić, "Spectral functions of damage index (DI) for masonry buildings with flexible floors", Tehnički vjesnik, vol. 25, no. 1, pp. 181-187, 2018. doi: 10.17559/TV-20170516090159.

[12] V.S.Biçen, E.Işı1k, M.H.Özlük, M. Ülker, "Solution for existing soil housetops of traditional Bitlis houses", International Engineering, Science and Education Conference (INESEC - 2016), Diyarbakir Turkey, 2016.

[13] E. Işık, "Evaluation of the masonry building stock in Bitlis province with street screening method" Bitlis Eren University, Journal of the Institute of Science, vol. 2, no. 1, pp.22-30, 2013.

[14] V.S.Biçen, E. Işık, “Geleneksel Bitlis evleri’nde yapı elemanları ve malzeme kullanımının örnek yap1 üzerinden değerlendirilmesi”, International Conference on Multidisciplinary, Science, Engineering and Technology (IMESET'18 Dubai). Dubai, 2018.

[15] E.Işık, M.C.Aydın, A.Büyüksaraç, A.E Ulu, "Structural analysis of historic houses of Bitlis", 4 th International Conference on Engineering and Natural Science (ICENS -2018), Kiev, Ukraine, 2018.

[16] W.Zhai, W.Zeng, "Building damage assessment using a single post-earthquake PolSAR image: a case of the 2010 Yushu earthquake", In IOP Conference Series: Earth and Environmental Science, vol. 57, no. 1, pp. 12-18, 2017.

[17] L.Xian, Z.He, X.Ou, "Incorporation of collapse safety margin into direct earthquake loss estimate", Earthquakes and Structures, vol. 10, no. 2, pp. 429450, 2016. doi: 10.12989/eas.2016.10.2.429 
[18] D.Gautam, G. Forte, H.Rodrigues, "Site effects and associated structural damage analysis in Kathmandu Valley, Nepal" Earthquakes and Structures, vol. 10, no. 5, pp. 1013-1032, 2016. doi:10.12989/eas.2016.10.5.1013

[19] H. S.Kim, C. K.Chung, "Integrated system for site-specific earthquake hazard assessment with geotechnical spatial grid information based on GIS", Natural Hazards, vol. 82, no. 2, pp. 981-1007, 2016.

[20] B. Bessason, J.Ö. Bjarnason, "Seismic vulnerability of low-rise residential buildings based on damage data from three earthquakes $(\mathrm{Mw}=6.5,6.5$ and 6.3)", Engineering Structures, vol. 111, pp. 64-79, 2016. doi: 10.1016/j.engstruct.2015.12.008.

[21] R. C.Sharma, R.Tateishi, K.Hara, H. T.Nguyen, S.Gharechelou and L. V.Nguyen, "Earthquake damage visualization (EDV) technique for the rapid detection of earthquake-induced damages using SAR", Data Sensors, vol. 17, no. 2, pp. 235, 2017. doi:10.3390/s17020235i:

[22] E.Isik, M. F.Isik, M. A.Bulbul, "Web based evaluation of earthquake damages for reinforced concrete buildings", Earthquakes And Structures, vol. 13, no. 4, pp. 387-396, 2017. doi:10.12989/eas.2017.13.4.423

[23] B.Taşkın, M.Aydoğan, M.Çelik, M Gençoğlu, K.Güler, Z.Hasgür, A.I.Saygun, Ü.M Tuğsal, "Deprem sonrasında betonarme binaların hasar sinıflandırılmasında kullanılacak yeni AFAD hasar tespit formlar1, No: 2010K140130 Hasar Tespit Sisteminin İyileştirilmesi Projesi”, TMMOB İş̧aat Mühendisleri Odası İstanbul Şubesi Meslekiçi Ĕgitim Semineri, 2015.

[24] K.Güler, M.Aydoğan, M.Çelik, M.Gençoğlu, K.Güler, Z. Hasgür, A.I.Saygun, B.Taşkın, Ü.M Tuğsal, "Deprem sonrasında yığma binaların hasar sinıflandırılmasında kullanılacak yeni AFAD hasar tespit formlar1, No: 2010K140130 Hasar Tespit Sisteminin İyileştirilmesi Projesi”, TMMOB Inşaat Mühendisleri Odası İstanbul Şubesi Meslekiçi Eğitim Semineri, 2015.

[25] M. Utkucu, H. Durmus, H.Yalçin, E. Budakoglu, E. Isik, "Coulomb static stress changes before and after the 23 October 2011 Van, eastern Turkey, earthquake $(\mathrm{MW}=7.1)$ : implications for the earthquake hazard mitigation", Natural Hazards and Earth System Sciences, vol. 13, no. 7, pp. 1889, 2013. doi:10.5194/nhess-13-1889-2013
[26] E. Işık, "The effects of 23.10. 2011 Van earthquake on near-field and damaged on structures", International Anatolia Academic Online Journal Science Journal, vol. 2, no. 2, pp. 10-25, 2014.

[27] E.Işık, M.H.Özlük, E.Demir, H.Bilici,. "23.10.2011 Van depreminin Adilcevaz ilçesindeki etkilerinin gözleme dayalı incelenmesi”, Bitlis, Eren Üniversitesi, Fen Bilimleri Enstitüsü Dergisi, vol. 1, no. 1, pp.1-10, 2012.

[28] L.Diaz, M. Lafont, J. M Munoz-Guijosa, S.Munoz, O.Echavarri, T.Chacon, O. De la Guerra, "Combining smart materials for enhancing intelligent systems: initial studies, success cases and research trends", Smart Structures and Systems, vol. 14, no. 4, pp.517-539, 2014.

[29] J. Broeders et al., "Mobile Application for Impedance-Based Biomimetic Sensor Readout," IEEE Sensors Journal, vol. 13, no. 7, pp. 2659-2665, July 2013. doi: 10.1109/JSEN.2013.2256346.

[30] Y. Ishigaki, Y. Matsumoto, R. Ichimiya and K. Tanaka, "Development of Mobile Radiation Monitoring System Utilizing Smartphone and Its Field Tests in Fukushima," IEEE Sensors Journal, vol. 13, no. 10 , pp. 3520-3526, Oct. 2013. doi: 10.1109/JSEN.2013.2272734.

[31] J. Lee, B. A. Reyes, D. D. McManus, O. Maitas and K. H. Chon, "Atrial Fibrillation Detection Using an iPhone 4S," IEEE Transactions on Biomedical Engineering, vol. 60, no. 1, pp. 203-206, Jan. 2013. doi: 10.1109/TBME.2012.2208112.

[32] C. Qin, X. Bao, R. R. Choudhury and S. Nelakuditi, "TagSense: Leveraging Smartphones for Automatic Image Tagging," IEEE Transactions on Mobile Computing, vol. 13, no. 1, pp. 61-74, Jan. 2014. doi: 10.1109/TMC.2012.235.

[33] P. Zheng, L. Ni, "Smart phone and next generation mobile computing", Morgan Kaufmann, 2010 .

[34] J. Andrus, C. Dall, A V. T. Hof, O. Laadan, J. Nieh, "Cells: a virtual mobile smartphone architecture", In Proceedings of the Twenty-Third ACM Symposium on Operating Systems Principles ACM, pp. 173-187, 2011.

[35] T. Y. Liu, W. L Chiang, C. W. Chen, W. K. Hsu, C. W Lin, D. J. Chiou, P. C.Huang, "RETRACTED: 
Structural system identification for vibration bridges using the Hilbert-Huang transform", Journal of Vibration and Control, vol. 18, no. 13, pp. 1939-1956, 2012. doi: $10.1177 / 1077546311428347$

[36] M. F. Iş̧1k, E. Iş̧1k, M. A. Bülbül, “Application of iOS/Android based assessment and monitoring system for building inventory under seismic impact", Građevinar, vol. 70, no. 12, pp. 1043-1056, 2018, doi: 10.14256/JCE.1522.2015

[37] E. Işık, M.F. Işık, M.A. Bülbül, "Betonarme binaların web tabanlı hızlı değerlendirilmesi”, Uludağ Üniversitesi, Mühendislik Dergisi, vol. 23, no. 1, pp. 225-234, 2018.

[38] İ.B. Karaşin, E. Işsk, M.F. Işık, M.A. Bülbül, "Web Tabanlı Yapı Hızlı Güvenlik Değerlendirmesi" International Conference on Multidisciplinary, Science, Engineering and Technology (IMESET'17) Bitlis, Türkiye, Oct. 27-29, 2017.

[39] E. Işık, M.F. Işık, "The application of iOS/Android based assessment and monitoring system for residential buildings", The 3rd CEPPIS International Scientific Conference on Civil Engineering: Present Problems, Innovative Solutions (CEPPIS2017), Poland, 2017.

[40] M. Ordaz, E. Reinoso, M. A. Jaimes, L. Alcántara, C. Pérez, "High-Resolution early earthquake damage assessment system for Mexico City based on a single-station", Geofisica International, vol. 56, no. 1, pp. 117-135, 2017. doi: 10.19155/geofint.2017.056.1.9

[41] S. Casciati, A. G. Chassiakos, S. F. Masri, , "Toward a paradigm for civil structural control", Smart Structures and Systems, vol. 14, no. 5, pp.9811004, 2014. doi: 10.12989/sss.2014.14.5.981 